\title{
Obituaries
}

\author{
HOLDEN FURBER
}

$(1903-1993)$

Professor Holden Furber, twenty-first president of the Association for Asian Studies and one of the founders of modern Indian historical studies, passed away in a peaceful sleep on January 19, 1993, in Bedford, Massachusetts. Born in Boston in 1903, Professor Furber received all his early education in the Boston area, where he attended Brookline High School preparatory to becoming a member of the Harvard Class of 1924. He earned a doctorate from Harvard in 1929 and at the same time attended Oxford University in England, where he was awarded a bachelor's degree in 1925 and a master's degree in 1930. In 1931, during his nine-year stint as an instructor at Harvard, he published his first book, Henry Dundas, First Viscount Melville, followed within two years by his edition of The Correspondence of Sir Jobn Shore, Governor General, with Henry Dundas, President of the Board of Control, 1793-1798. Professor Furber's promise as a young scholar was recognized with the award of a Guggenheim Fellowship in 1937-38. He was appointed an assistant professor at the University of Texas in 1940 but soon received an assignment to the Office of Strategic Services to work as a social science analyst. From 1943 to 1945, he served the State Department as a specialist on the British Commonwealth, then returned to the University of Texas until 1948.

It was then that Professor Furber published his most creative book, Jobn Company at Work. For this study of the country trade in Asia, that is to say, European trade from one point in Asia to another, he ransacked Dutch, French, and Danish, as well as British archives. He established that private British trading interests linked up with Indian merchants to play a dynamic role in a vital network of trade which ultimately led to the foundation of the British raj in India. The American Historical Association honored this book with the Watumull Prize in 1949. Meanwhile, Professor Furber had lectured at the University of Madras in 1948, prior to moving on to the University of Pennsylvania, where he remained as Professor of History until 1973. It was at the University of Pennsylvania that he formed a close relationship with W. Norman Brown and contributed substantially to the building of a program for the study of the Indian subcontinent. He traveled to India in 1962 to deliver the Heras Lectures at the University of Bombay, which were published under the title The Bombay Presidency in the Mid-18th Century. In 1965 he edited, with the assistance of P. J. Marshall, volume five of the series entitled The Correspondence of Edmund Burke. This volume covered the period July 1782-June 1789 during which Burke's constructive interest in Indian affairs yielded to an "implacable determination" to win a victory over Hastings in the latter's impeachment trial. Professor Furber found in these letters re-enforcement for the "view held in India today" of Burke as "champion of Bengal's downtrodden millions."

Professor Furber was a member of the Royal Historical Society and served as president of the Association for Asian Studies in 1968-69. After his retirement, 
he published his ambitious survey, Rival Empires of Trade in the Orient 1600-1800, which projected the themes of Jobn Company at Work back to earlier times.

Professor Furber's last book was dedicated to Elizabeth Chapin Furber, his first wife and a scholar of medieval French history, who tragically died at the time of his retirement. Lucy Richardson, his second wife, was a classmate's widow, whom he escorted to his fiftieth reunion at Harvard. They married seven years later and alternated between his summer home at Marblehead, Massachusetts, and her family home in Concord, Massachusetts, where Mrs. Furber arranged a memorial service for her late husband in the historic First Parish Unitarian Universalist Church on January 26, 1993.

Holden Furber's distinguished career is well established, but a list of accomplishments inevitably fails to provide the full measure of his personality. Holden Furber was an unfailing friend, gentleman scholar, and upholder of liberal values. The reach of his scholarly reputation, despite his personal modesty, was brought home to me on a winter evening in 1974 in the living room of Professor O. P. Bhatnagar of Allahabad University. In the course of extending me the warmest hospitality as a research scholar visiting Allahabad, Professor Bhatnagar reminisced extensively about his friendship with Professor Furber, and spoke of how John Company at Work had inspired a generation of Indian historians. Long after his retirement, Holden Furber would send me thoughtful and helpful commentary about my own published work or about current controversies. Needless to say, I shall always feel proud to have been a part of his network of friends, colleagues, and students. Perhaps, it is still not too late to honor the exhortation of his presidential address delivered in 1969, the centenary of Mahatma Gandhi's birth. He urged us to:

get on with the work of building a new partnership between West and East, a . . . collaboration without undertones of superiority on either side and above all, without the military presence of the European, a collaboration some day symbolized perhaps by some future Gandhi born in this unhappy period through which we are passing.

Nancy Gardner Cassels

Dundas, Ontario

\section{BARBARA STOLER MILLER}

$$
(1940-1993)
$$

Barbara Stoler Miller was every inch a New Yorker, born in New York City on August 8,1940, and educated there at Barnard College and Columbia University, where she earned her B.A. in philosophy from 1959 to 1962 and her M.A. in Indic Studies from 1962 to 1964 . Her talents were evident even then; she was elected to Phi Beta Kappa, won the Montague Philosophy Prize, and was awarded her degree magna cum laude at Barnard in 1962. She went on to earn, in 1968, a Ph.D. in Indic Studies, with distinction, from the University of Pennsylvania, where she 